\title{
Knowledge and Attitudes of Nursing Students toward Human Papilloma Virus Vaccination
}

\section{Hayam Magdy ELsayed Mohammed ${ }^{1}$, Mohamed Abd El-Salam Mohamed ${ }^{2}$, Soad Abd El-Salam Ramadan $^{3}$ and Somaya Ouda Abd EL-Monem ${ }^{4}$}

(1) B.SC in Nursing 2013, (2) Professor of Obstetrics and Gynecology, Faculty of Medicine, Benha University, (3) Professor of Obstetrics and Gynecological Nursing, Faculty of Nursing Benha University and (4) Assist prof of Obstetrics and Gynecological Nursing, Faculty of Nursing, Benha University

\begin{abstract}
Background: Human Papilloma Virus (HPV) infection is the most common sexually transmitted disease in the world and the leading cause of cervical cancer. Aim: This study aimed to assess the knowledge and attitudes of nursing students toward human papilloma virus vaccination. Setting: The study was conducted at the Faculty of Nursing - Benha University. Design: A descriptive design was used to conduct the study. Sampling: Systematic random sample included 195 students were recruited in the study. Tools: Two tools were utilized for data collection, interviewing questionnaire sheet and modified likert scale. Results: About half of studied nursing students $(52.8 \%)$ with mean age of $20.74 \pm 1.42$ were 20 years old, the highest percentage of them $(79.0 \%)$ were female and more than one quarter of them $(29.2 \%)$ were in the first year. About two third of studied nursing students $(67.2 \%)$ $(65.1 \%)$ had an average knowledge about human papilloma virus and pap smear and slightly more than half of them $(59.5 \%)$ had an average knowledge about vaccination. Also, the highest percentage (72.3\%) of studied nursing students had positive attitudes toward Pap smear, HPV and vaccination. Conclusion: There was statistically significant relation between total knowledge and total attitudes among nursing students. Recommendation: HPV vaccines should be included in national immunization programs.
\end{abstract}

Key words: Attitudes, Cervical cancer, Human papillomavirus, Knowledge, Vaccination

\section{Introduction}

Viral infections contribute to $15-20 \%$ of all human cancers, whereby several viruses play major roles in the growth of malignant cancers. One of these viruses is human papillomavirus. HPV is a virus that can be sexually transmitted, and high-risk HPV DNA is found to be present in $99.7 \%$ of cervical cancer specimens. HPV is a double-stranded DNA virus belonging to the papovaviridae family. Almost 200 HPV types have been identified with more than 40 types colonizing the genital tract (Chan et al., 2019).

The infection of HPV is commonly acquired through skin warts, by sexual intercourse (genital warts), during passage through an infected birth canal, autoinoculation or by oral sex that can lead to oral papilloma. Oral HPV infection can, rarely, be a potential health hazard to newborn babies in the form of juvenile recurrent respiratory papillomatosis. Also transmission may occur via fomites and 
Knowledge and Attitudes of Nursing Students toward Human Papilloma Virus Vaccination

medical procedures, but transmission to the external genitalia through fomites is rare (Liu et al., 2018).

Most persons infected with HPV are asymptomatic but transmission of the infection without visible lesions is common. Anogenital HPV is associated with cutaneous warts so autoinfection can occur from one site to another. Population at least $80-90 \%$ of genital HPV infection clear spontaneously over time (Chin Hong et al., 2019).

High-risk types 16 and 18 account for almost $70 \%$ of all cervical cancers, as well as about $90 \%$ of the anal cancers and a variable fraction of vulvar, vaginal, penile and oropharyngeal cancers. HPV genotypes 31,33 , 45, 52 and 58 are the etiological agent for more than $20 \%$ of cervical cancers. Low-risk genotypes 6 and 11 mainly cause cervical, vulvar and vaginal low-grade lesions, and are responsible for $90 \%$ of the anogenital warts or condyloma acuminatum (Medeiros et al., 2020).

Genital condyloma acuminata are defined as warts around the genital and anal areas. HPV type 6 and 11are responsible for more than $90 \%$ of genital warts .In women, external genital warts are always characterized by flat or exophytic warts of the vagina and cervix .In men, genital HPV infection is manifested by the presence of condyloma acuminata of genital areas, penile intraepithelial neoplasia and penile carcinoma (Al-Awadhi et al.,(2019).

Three types of prophylactic vaccines, quadrivalent HPV vaccine, bivalent HPV vaccine, and the nonavalent HPV vaccine have been approved for use in many countries. These three vaccines prevent $70 \%-90 \%$ of the HPV- related cancers with its advantages of safety and effectiveness. The quadrivalent and nonavalent HPV vaccines also protect against HPV6 and HPV11, which cause anogenital warts (Wang et al., 2020).

The HPV vaccination is recommended for females aged 9 through 26 years and males aged 13 through 21 years. HPV vaccines are most effective when administered prior to becoming sexually active and possible exposure to HPV, as they do not treat existing infections (Chanprasertpinyoand Rerk swa ttavorn, 2020).

One of the major risk factors for the development of cervical cancer is HPV so nurses have a major for prevention of the disease. The nurse can give health education through the levels of prevention. Primary prevention involves targeting people who have not been infected with HPV. This is achievable through behavior modification to manage risk factors by introducing the idea of abstinence, using condoms, and delay in the age of first sexual intercourse, as well as avoiding multiple sexual partners, and taking the vaccination of hpv. Secondary prevention focuses on screening and early detection, followed by treatment of precancerous lesions. Tertiary prevention includes diagnosis and treatment of invasive cervical cancer and palliative care (Ifediora, 2019).

Nurses are responsible for giving information to parents and students about HPV vaccinations. The nurse must take into account factors that affect acceptance of HPV vaccination such as parental beliefs, trust in vaccine safety, cultural norms and values related to sexual activity, as well as sociodemographic factors. Nurses, play a major role in successful HPV vaccination programs, 


\section{Hayam Magdy, Mohamed Abd El-Salam, Soad Abd El-Salam Ramadan and Somaya Ouda}

especially giving information and addressing vaccine hesitancy (Grandahl et al., 2019).

Nurses play an important role in preventing HPV infection and cervical cancer because the nurses are responsible to provide health education and promotion services for the students by organizing educational programs, conferences, distributing booklets or brochures to increase students' knowledge, positively change the attitude and create awareness about HPV infection as well as counseling all students to receive preventive immunization including the HPV vaccination (Atitt-Allah et al., 2019).

\section{Significance of the study}

Worldwide, HPV is responsible for $5.1 \%$ of the burden of cancer and is present in nearly $100 \%$ of cervical tumors, $88 \%$ of anal tumors and $50 \%$ of penile tumors. HPV-16 is the most commonly found genotype in head and neck squamous cell carcinomas, while overall HPV prevalence in these lesions is $26 \%$ (Colpani et al.,2020).

In Egypt, 969 cervical cancer cases and 631 deaths caused by cancer annually. Cervical cancer represents the second most common cancer among Egyptian women and the 10th most common cancer among women between 15 to 44 years. High-risk HPVs are likely to be responsible for about $70 \%$ of cervical cancer cases. In North Africa; where Egypt lies, 81.2\% of invasive cervical cancers are approved for high-risk HPVs (Marzouk and Fadel, 2020).

Health care professionals need to be knowledgeable about the causes, signs and symptoms, transmission of cervical cancer and prevention strategies, especially HPV vaccination and work towards raising public awareness about this important public health concern. Similarly, nursing students need to be knowledgeable about these important topics, because patient education and counseling, to promote sexual health and prevent cervical and other cancers, is an integral part of nursing practice. Faculty of nursing may play a key role in ensuring that future nurses' are educated about the relationship between HPV and cancers and are aware and accept prevention strategies, so this study will be conducted to assess knowledge and attitude of nursing students (Agyei-Baffour et al., 2020).

\section{Aim of study}

This study aimed to assess the knowledge and attitudes of nursing students toward human papilloma virus vaccination.

\section{Research questions}

1- What is the knowledge of nursing students toward Human papillomavirus vaccination?

2- What are the attitudes of nursing students toward Human papillomavirus vaccination?

\section{Subject and methods}

\section{Research design:}

A descriptive design was used to conduct the study.

\section{Research setting:}

The study was conducted at the Faculty of Nursing - Benha University.

\section{Sample:}

\section{Type of sample:}

Systematic random sample

\section{Sample size:}

Total of sample was 195 students. 
Knowledge and Attitudes of Nursing Students toward Human Papilloma Virus Vaccination

It was calculated as: $10 \%$ of the total number of students of the faculty year (2019-2020).

\section{Sample technique:}

The study included the first, second, third and fourth grade. The first grade included 558 students, the second 478 students, the third 461 and the fourth grade 452 . The total number of students in the four grades was 1949 students. The study was conducted on 195 students which considered the representative sample that was chosen by systematic random sample as

Suppose total numbers of students (N)

Suppose representative sample (n)

Sample interval (L)

$\mathrm{L}=\mathrm{N} / \mathrm{n} 1949 / 195=10$.

Every ten students selected one student until complete.

\section{Tools of data collection:}

Two tools were used for collecting data:

Tool I: A structured interviewing questionnaire: was adapted by (Omar, 2015) and was modified by researcher after reviewing a related literature and translated into Arabic language. It included the following:

Part1: Socio-demographic data concerning with: (age, sex, academic year, smoking status, marital status, HPV vaccination status)

Part 2: student and family history of cervical cancer: Assessing family history of studied nursing students at Faculty of Nursing Benha University through items written in Arabic language in the form of complete questions. It included 10 items.

Part 3: Nursing Students' knowledge about HPV: Assessing knowledge of studied nursing students at Faculty of Nursing Benha University it includes three parts.

- Knowledge about HPV: it included 3 questions.

- Knowledge about cervical cancer and Pap smear: it included 7 items.

- Knowledge about HPV vaccines: it included 8 questions.

\section{Knowledge's scoring system:}

All knowledge variables were weighted according to items included in each question. The answer would score (2) for correct answer. The answer would score (1) for incomplete answer, while the answer would score (0) for incorrect answer.

\section{Scoring system:}

The total score was considered good $>75 \%$ equal 27 point, while the total score was considered poor $<50 \%$ equal 18 point and was considered average $50-75 \%$ equal $18-27$ point (Aboelfottoh,2014)

\section{Tool II: Nursing students' attitudes toward HPV vaccines:}

The attitudes scale was adapted by (Omar, 2015) and it comprised 19 statements on 3 point Likert Scale (agree, uncertain and disagree)

\section{Scoring system:}

To obtain the outcome of attitude scale, each statement scored as (2) if the response was "agree", (1) if it was "uncertain" and (0) if it was "disagree".

The total score is expressed as a percentage.

The total score of attitude was considered positive $>80 \%$ equal more than 30 point and 


\section{Hayam Magdy, Mohamed Abd El-Salam, Soad Abd El-Salam Ramadan and Somaya Ouda}

was considered negative $<80 \%$ equal less than 30 point .

\section{Validity of the study tools:}

Content validity of tools was assessed by three experts in obstetric and gynecological nursing field. The questionnaire was modified according to the expert's comments.

\section{Reliability of the tools:}

Reliability of tools was measured by using Cronbach's alpha and the value was 0,892 for reliability of knowledge and 0,759 for reliability of attitudes

\section{Ethical considerations:}

-An official permission from the selected study settings will be obtained for fulfillment of the study.

-The aim of the study will be explained to each student before applying the tools to gain their confidence and trust.

-The researcher will take oral consent from student to participate in the study and confidentialities will be assured.

-The data will be collected and treated confidentially.

\section{Pilot study}

Carried out on $10 \%$ of students (19 students) would conducted to test the clarity and applicability of the tools, the necessary modification will be done according the pilot study.

\section{Field work}

The study was implemented for three months from beginning of july to the end of September. The data would be collected by using the previous study tools. This would be done at Faculty of Nursing at Benha University. The researcher visited the Faculty of Nursing 2days/week from 9Am to 2Pm. The researcher greated the students and introduced herself then explain the purpose of the study to gain their cooperation .The researcher obtained the oral consent from the students then applying the research. the researcher collected student in small group about10-15 student in each group with taken precautions and preventative measure during collected data the time of each sheet 20-30 minute The researcher explained the questionnaire sheet to the students. The researcher ensured that all questions were be answered and then collected the questionnaire sheet from every students. This technique would be repeated to every Academic year until completed the sample.

\section{Statistical analysis:}

Computerized data entry and statistical analysis were fulfilling scored using Statistical Package for Social Science (SPSS) version 20. Descriptive statistic was applied (frequency, percentage) for qualitative data and using Chi-squre to determine significant, using mean and standard deviation for quantitative data and correlation coefficient was used to test " $\mathrm{r}$ ".

\section{Results}

Table (1): Shows that about half of studied nursing students $(52.8 \%)$ with mean age of $20.74 \pm 1.42$ were 20 years old in the age group, the highest percentage of studied nursing students $(79.0 \%)$ were female, more than one quarter of studied nursing students (29.2\%) were in the first year, the total number of studied nursing students $(100 \%)$ were no smoker, the majority of them $(89.2 \%)$ were 
single and the total number of them were not vaccinated.

Table (2): Shows that the total number of studied nursing students $(100 \%)$ had no tumors , the highest percentage of them ( $87.7 \%$ ) had no tumors in their families and the lowest percentage of them $(12.3 \%)$ had first degree family tumors.

Figure (1): Shows that $61 \%$ of studied students have average total knowledge regarding HPV.
Table (3): Shows that slightly more than two third of studied nursing students $(68.2 \%)$ agreed with pap smear, slightly less than two third $(62,6 \%)$ of them were uncertain with HPV and about half of them $(52,8 \%)$ agreed with vaccination.

Table (4): Shows that there was statistically significant relation between total knowledge and total attitudes among studied nursing students

Table (1): Frequency distribution of studied nursing students regarding their personal characteristics $(n=195)$.

\begin{tabular}{|c|c|c|}
\hline Personnel characteristics & No & $\%$ \\
\hline \multicolumn{3}{|l|}{ Age } \\
\hline $19-20$ & 103 & 52.8 \\
\hline $21-22$ & 87 & 44.6 \\
\hline$>22$ & 5 & 2.6 \\
\hline \multicolumn{3}{|l|}{ Mean $\pm \mathrm{SD}=20.74+-1.42$} \\
\hline \multicolumn{3}{|l|}{ Sex } \\
\hline Male & 41 & 21.0 \\
\hline Female & 154 & 79.0 \\
\hline \multicolumn{3}{|l|}{ Academic year } \\
\hline First & 57 & 29.2 \\
\hline Second & 47 & 24.1 \\
\hline Third & 46 & 23.6 \\
\hline Fourth & 45 & 23.1 \\
\hline \multicolumn{3}{|l|}{ Smoking behavior } \\
\hline Non smoker & 195 & 100.0 \\
\hline \multicolumn{3}{|l|}{ Marital status } \\
\hline Single & 174 & 89.2 \\
\hline Married & 21 & 10.8 \\
\hline \multicolumn{3}{|l|}{$\begin{array}{l}\text { The status of vaccination } \\
\text { against human papillomavirus }\end{array}$} \\
\hline Not vaccinated & 195 & 100.0 \\
\hline
\end{tabular}


Table (2): Frequency distribution of studied nursing students regarding their family history $(n=195)$.

\begin{tabular}{|l|l|l|}
\hline Items of students and family history & No & $\%$ \\
\hline you ever have not had tumors & 195 & 100.0 \\
\hline The type of disease is none & 195 & 100.0 \\
\hline The tumor location is none & 195 & 100.0 \\
\hline you currently do not suffer from any tumors & 195 & 100.0 \\
\hline The type of tumor is none & 195 & 100.0 \\
\hline The tumor located is none & 195 & 100.0 \\
\hline Anyone in your family had any tumors & & \\
\hline Yes & 24 & 12.3 \\
\hline No & 171 & 87.7 \\
\hline $\begin{array}{l}\text { The degree of kinship to this person? } \\
\text { (n=24). }\end{array}$ & & \\
\hline First degree(father, mother, and daughter, son) & 14 & 58.3 \\
\hline Second degree(grandfather, grandmother and sisters) & 6 & 25.0 \\
\hline Third degree (nephew, aunt and uncle). & 3 & 12.5 \\
\hline Fourth degree(cousin and the paternal aunt) & 1 & 4.2 \\
\hline
\end{tabular}

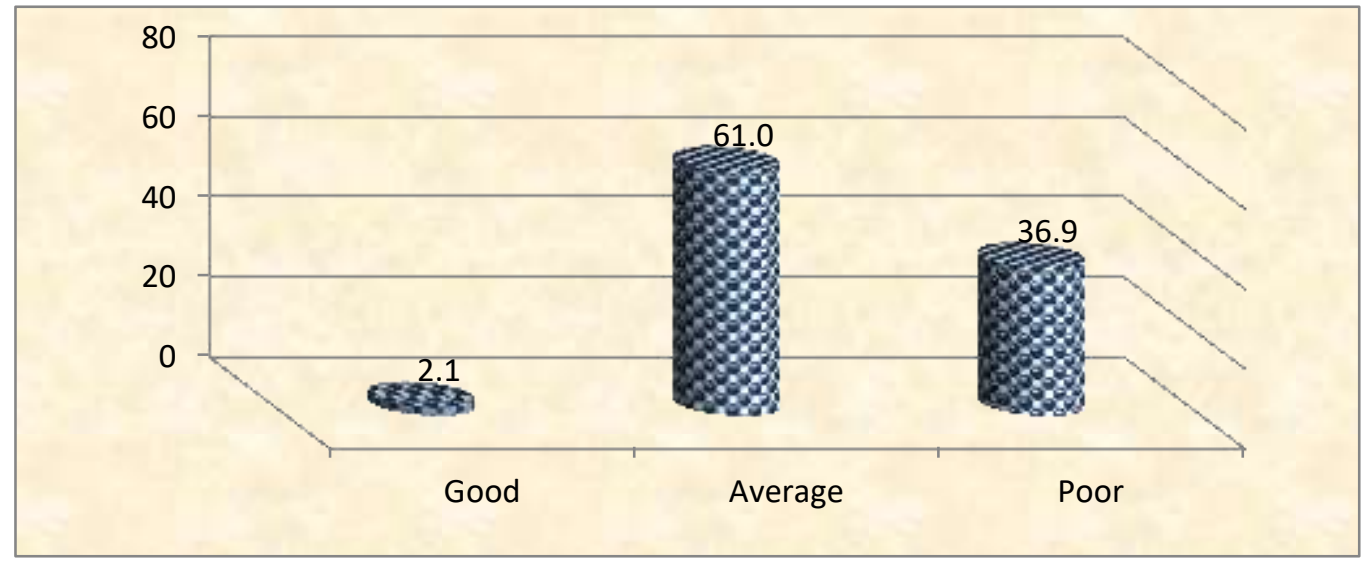

Figure (1): Percentage distribution of studied students regarding general knowledge about HPV 
Knowledge and Attitudes of Nursing Students toward Human Papilloma Virus Vaccination

Table (3): Frequency distribution of studied nursing students regarding total attitude items about pap smear, HPV and vaccination $(\mathrm{N}=195)$.

\begin{tabular}{|l|l|l|l|l|l|l|}
\hline \multirow{2}{*}{ Items } & \multicolumn{2}{l}{ Agree } & \multicolumn{2}{l|}{ Uncertain } & \multicolumn{2}{l|}{ Disagree } \\
\cline { 2 - 8 } & No & $\mathbf{\%}$ & No & $\boldsymbol{\%}$ & No & $\%$ \\
\hline Total Pap smear attitude & 133 & 68.2 & 48 & 24.6 & 14 & 7.2 \\
\hline Total HPV attitude & 122 & 62.6 & 62 & 31.8 & 11 & 5.6 \\
\hline Total vaccination attitude & 103 & 52.8 & 77 & 39.5 & 15 & 7.7 \\
\hline
\end{tabular}

Table (4): Statistically correlation between total knowledge and total attitude among studied nursing students $(\mathrm{N}=195)$.

\begin{tabular}{|l|l|l|}
\hline \multicolumn{3}{|c|}{ Total knowledge } \\
\hline Total attitude & $\mathrm{R}$ & $\mathrm{p}$-value \\
\cline { 2 - 3 } & 0.216 & $0.002 *$ \\
\hline
\end{tabular}

* Statistically significance (P value $\leq 0.001)$

\section{Discussion}

As regards characteristics of studied nursing students, the result of the present study showed that half of studied nursing students with mean age of $20.74 \pm 1.42$ were 20 years old in the age group, because the largest number of students was from the first year. The highest percentage of studied nursing students were female, this due to most of students in the faculty are females. More than one quarter of studied nursing students were in the first year, this because the first year of students has the largest number of students in the faculty. Also all of studied nursing students were no smoker and the majority of them were single.

This result is near similar with Shetty et al.,(2019) who studied(Knowledge, attitudes and factors associated with acceptability of human papillomavirus vaccination among undergraduate medical, dental and nursing students in South India)findings revealed that about half of studied nursing students were between the ages 20-22 years, the highest percentage of the students were female, about one third of the students were in the first year ,the majority of them were no smoker and the majority of them were single ..Also this result in agreement with Mohamed etal.,(2019)who studied (Awareness about breast and cervical cancers among nursing students in Beni-Suef University)the results revealed that the highest percentage were female .

This result is near similar to Villanueva Penerbosa, (2019) who studied (Knowledge, Attitudes, and Intentions towards Human Papillomavirus Vaccination among Nursing Students in Spain) findings revealed that the highest percentage of nursing students were female and about one third of nursing students were in the first year. On opposite of that Kamberi and Muhaj,(2019) who studied (Knowledge and Health Beliefs of Nursing 


\section{Hayam Magdy, Mohamed Abd El-Salam, Soad Abd El-Salam Ramadan and Somaya Ouda}

Students Toward Human Papilloma Virus and Vaccine Use) findings reveals that the majority of students were female and the majority of them were single .

This result disagreed with Cinar et al., (2019) who studied (Knowledge and Behavior of University Students toward Human Papillomavirus and Vaccination) which reported that less than half of studied nursing students were between the ages 21-22 years and more than half were male. Also incongruent with Hino et al., (2016) who studied (Knowledge of undergraduate nursing students about human papillomavirus vaccine) showed that more than one third of students were in the fourth year.

Regarding status of vaccination of studied nursing students the results of current study revealed that all studied nursing students were not vaccinated. These findings may be due to the students are un aware of the availability and safety of the vaccine and other students believed that the vaccination causes health problems. The results were in accordance with Cinar et al.,(2019) found that the majority of studied nursing students were not vaccinated .Also this result agreed with Aslan and Bakan ,(2020) who studied (Identification of the Knowledge Level of Students Receiving Health Education About the Human Papilloma Virus, Screening Tests, and Human Papilloma Virus Vaccination) found that the majority of studied nursing students were not vaccinated. On the other hand, the results disagreed with Natipagon-Shah et al., (2020) who studied (Knowledge, Beliefs, and Practices among U. S. College Students Concerning Papillomavirus Vaccination) revealed that more than half of nursing students had been vaccinated with one dose.
Concerning family history of studied nursing students the result of current study revealed that the majority of studied nursing students had no tumors in their families. This result is in accordance with Aslan and Bakan ,(2020) who reported that the majority of studied nursing students had no tumors in their families. Additionally, the result of present study illustrates that the lowest percentage of studied nursing students had tumors in their families. Moreover, two third of their families had malignant tumors and one quarter of their families had breast and liver cancer. This result is near similar with Mohamed et al., (2019) who found that the lowest percentage of nursing students reported a family history of breast cancer and/or cervical cancer.

According to total attitudes of studied nursing students about HPV, the vaccination and cervical cancer with pap smear. The present study showed that slightly more than two third of studied nursing students agreed with cervical cancer and pap smear this may be due to the students reported that they studied its complications, slightly less than two third of them were uncertain with HPV this may be attributed to lack of complete knowledge about causative role of HPV in carcinoma cervix and about half of them agreed with vaccination. These findings were matched with AbdAllah et al.,(2016)concluded that about more than two third of nursing students agreed with cervical cancer and pap smear .Also Shetty et al.,(2019) found that less than half of the students agreed with pap smear.

The results agreed with Yesaya, (2020) reported that less than half of the participants were uncertain with HPV and about half of them agreed with the vaccination. 
Knowledge and Attitudes of Nursing Students toward Human Papilloma Virus Vaccination

On investigating correlation between total knowledge and total attitudes among nursing students, the results revealed that there was statistically significant relation between total knowledge and total attitudes among studied nursing students. This can be due to the average knowledge of students toward human papillomavirus increases their attitudes toward the vaccination .This supports the necessary need for publishing health educational intervention especially regarding issues such as HPV and the HPV vaccine to increase vaccine uptake rates, which is mainly sexually transmitted disease. So, increasing students' knowledge about human papilloma virus infection increases their attitudes for taking the vaccination. In this context, the result was in accordance with Attit-Allah et al.,(2019) revealed that there was statistically significant relation between total knowledge and total attitudes among studied nursing students. Furthermore, the results came on the opposite of Fakor et al., (2016) who studied (Knowledge and Attitudes of Medical Students about Human Papilloma Virus (HPV) Vaccination and Associated Factors) reported that there was no statistically significant relation between total knowledge and total attitudes among students.

\section{Conclusion}

Two third of studied nursing students had an average knowledge about human papilloma virus and cervical cancer. Moreover, slightly more than half of studied nursing students had an average knowledge about vaccination. Also, the highest percentage of studied nursing students had positive attitudes toward pap smear, HPV and vaccination. Furthermore, there was statistically significant relation between total knowledge and total attitudes among nursing students. The above mentioned findings have mainly answered the study questions.

\section{Recommendations}

- Conducting educational and reproductive health programs including the causal association between HPV infection and cancer cervix, the types of vaccination and highlight the importance of vaccination to susceptible groups.

- Also, establishing educational programs with for students to increase mothers' awareness of vaccination, because in this study most students, their mothers affect their decision to take the vaccine.

- Availability of poster and written materials at faculty of nursing about importance of HPV vaccination.

\section{Further study need to be performed:}

- HPV vaccines should be included in national immunization programs.

- A follow-up study can be suggested to detect vaccination uptake incidence; to conclude whether the provided knowledge translates into higher rates of vaccination.

- Further research should be targeted to health-care givers because of their important role in screening programs and spreading health information about cervical cancers.

\section{References}

AbdAllah, A., Hummeida, M.and Elmula, I. (2016). Awareness and Attitudes of Nursing Students towards Prevention of Cervical Cancer, Cervical Cancer, 1(106), 2-3. 
Hayam Magdy, Mohamed Abd El-Salam, Soad Abd El-Salam Ramadan and Somaya Ouda

Aboelfottoh,S. (2014).Application of Health Belief Model on Nursing Students' Perception regarding Benefits of Preconceptional Folic Acid Intake,( Master Thesis, Faculty of Nursing, Benha University,42) .

Agyei-Baffour, P., Asare, M., Lanning, B., Koranteng, A., Millan, C., Commeh, M. E.and Mamudu, H. (2020). Human Papillomavirus Vaccination Practices and Perceptions among Ghanaian Healthcare Providers: A qualitative Study Based on MultiTheory Model, PloS one, 15(10), e0240657.

Al-Awadhi, R., Al-Mutairi, N., Albatineh, A.and Chehadeh, W. (2019). Association of HPV Genotypes with External Anogenital Warts: across Sectional Study, BMC infectious diseases, 19(1), 1-7.

Aslan, G.,and Bakan, A. (2020). Identification of the Knowledge Level of Students Receiving Health Education About the Human Papilloma Virus, Screening Tests, and Human Papilloma Virus Vaccination, Journal of Community Health, 1-6. https://doi.org/10.1007/s10900020-00888-8.

Atitt-Allah, N., Abd-Elhady, R. and Araby, O. (2019).Effect of Educational Intervention on Knowledge and Attitudes Regarding Human Papillomavirus Infection and Its Vaccination among Nursing Students.,American Journal of Nursing, 7(4), 453-464.

Chan, C., Aimagambetova, G., Ukybassova, T., Kongrtay, K.and Azizan, A. (2019). Human Papillomavirus Infection and Cervical Cancer: Epidemiology, Screening, and Vaccination-Review of Current Perspectives, Journal of Oncology, 1-11.

Chanprasertpinyo,W.and Rerkswattavorn, C. (2020). Human Papillomavirus (HPV)
Vaccine Status and Knowledge of Students at A university in Rural Thailand, Heliyon, 6(8), e04625.1-6

Chin-Hong, P., Reid, G., \& AST Infectious Diseases Community of Practice. (2019). Human papillomavirus infection in solid organ transplant recipients: Guidelines from the American Society of Transplantation Infectious Diseases Community of Practice. Clinical transplantation, 33(9), 13590.

Cinar, İ. , Ozkan, S., Aslan, G. and Alatas, E. (2019). Knowledge and Behavior of University Students toward Human Papillomavirus and Vaccination, Asia-Pacific Journal of Oncology Nursing, 6(3), 300.

Colpani, V., Soares Falcetta, F., Bacelo Bidinotto, A., Kops, N., Falavigna, M., Serpa Hammes, L.and Wendland, E. (2020). Prevalence of Human Papillomavirus (HPV) in Brazil: A systematic Review and Metaanalysis, PloS one, 15(2), e0229154.

Fakor, F., Mahfouzi, L., Dalil Heirati, S.and Graili, S. (2016). Knowledge and Attitudes of Medical Students about Human Papilloma Virus (HPV) Vaccination and Associated Factors, Journal of Holistic Nursing And Midwifery, 26(4), 71-79.

Grandahl, M., Larsson, M., Dalianis, T., Stenhammar, C., Tyden, T., Westerling, R.Neveus, T. (2017). Catch-up HPV vaccination status of adolescents in relation to socioeconomic factors, individual beliefs and sexual behaviour. PLoS One, 12(11), 2-3.

Hino, P., de Freitas, N., de Carvalho Onofre, P., de Souza, K.and de Oliveira Santos, J. (2016). Knowledge of undergraduate nursing students about human papillomavirus 
Knowledge and Attitudes of Nursing Students toward Human Papilloma Virus Vaccination

vaccine, Revista da Rede de Enfermagem do Nordeste, 17(5), 586-592.

Ifediora, C. (2019). Re-thinking Breast and Cervical Cancer Preventive Campaigns in Developing Countries: the Case for Interventions at high Schools, BMC Public Health, 19(1), 1-8.

Kamberi, F.and Muhaj, E. (2019).Knowledge and Health Beliefs of Nursing Students toward Human Papilloma Virus and vaccine use. Asian Pacific Journal of Cancer Care, 4(2), 27-32.

Liu, Z., Nyitray, A., Hwang, L., Swartz, M., Abrahamsen, M., Lazcano-Ponce, E.and Giuliano, A. (2018). Acquisition, Persistence, and Clearance of Human Papilloma Virus Infection among Male Virgins Residing in Brazil, Mexico, and the United States, The Journal of infectious diseases, 217(5), 767-776.

Marzouk, T.and Fadel, E.(2020). Effect of a lecture-based Education on Female Undergraduates' knowledge and Acceptance of the Human Papillomavirus Vaccine for Cervical Cancer Prevention, Journal of Nursing and Health Science,9(1)57-68.

Medeiros, R., Vaz, S., Rebelo, T.and Figueiredo-Dias, M. (2020). Prevention of Human Papillomavirus Infection. Beyond Cervical Cancer: A Brief Review, Acta Médica Portuguesa, 33(3), 198-201.

Mohamed, A., Hassan, H., Gamel, W.and Arafa, A. (2019). Awareness about Breast and Cervical Cancers among Nursing Students in Beni-Suef University, Journal of Nursing Education and Practice, 9(5), 44-51.
Natipagon-Shah, B., Lee, E.and Lee, S. (2020). Knowledge, Beliefs, and Practices Among US College Students Concerning Papillomavirus Vaccination, Journal of Community Health, 1-9. https://doi.org/10.1007/s10900-020-00922-9

Omar, R. (2015). Knowledge and Attitudes of Maternity Nurses Regarding Vaccination against Human Papilloma Virus, (Master Thesis, Faculty of Nursing, Alexandria University, 9-10).

Shetty, S., Prabhu, S., Shetty, V.and Shetty, A. (2019).Knowledge, Attitudes and Factors Associated with Acceptability of Human papillomavirus vaccination among Undergraduate Medical, Dental and Nursing Students in South India, Human Vaccines and Immunotherapeutics, 15(7-8), 1656-1665.

Villanueva Penerbosa, S., Mosteiro Miguéns, D., Domínguez Martís, E., López Ares, D.and Novío Mallón, S. (2019). Knowledge, Attitudes, and Intentions towards Human Papillomavirus Vaccination among Nursing Students in Spain 16(22),4.

Wang, R., Pan, W., Jin, L., Huang, W., Li, Y., Wu, D.and Liao, S. (2020). Human Papillomavirus vaccine against Cervical Cancer: Opportunity and Challenge, Cancer letters, 471, 88-102.

Yesaya, D. (2020). Knowledge, Attitude, and Practice towards Human Papilloma Virus (HPV) and its Vaccination among Students at the University of Eastern Finland (Master's thesis, Faculty of Health sciences, University of Eastern Finland, 4-74). 
معلومات واتجاهات طلاب التمريض تجاه التطعيم ضد فيروس الورم الحليمي البشري

هيام مجدي السيد - محمد عبدالسلام محمج سعاد عبدالسلام رمضان - سميه عوده عبدالمنعم

عدوى فيروس الورم الحليمي البشري هي أكثر الأمراض التي تتتقل عن طريق الاتصال الجنسي شيوعًا في العالم و السبب الرئيسي لسرطان عنق الرحم. لذلك هدفت هذه الدراسة الى تقييم معلومات واتجاهات طلاب التمريض تجاه التطعيم ضد فيروس الورم الحليمي البشري. وقد أجريت الدراسة بكلية التمريض - جامعة بنهاعلى 190 طالبَ وطالبة. حيث كشفت النتائج عن ان هناك علاقة ذو دلالة إحصائية بين المعرفة الكلية والاتجاهات الكلية لدى طلاب التمريض. كما أوصت الدراسة إجر اء برامج تثقيفية بما في ذلك العلاقة السببية بين الإصسابة بفيروس الورم الحليمي البشري وسرطان عنق الرحم و أنواع التطعيم وإبراز أهمية التطعيم للفئات المعرضة للإصابة بـ. 